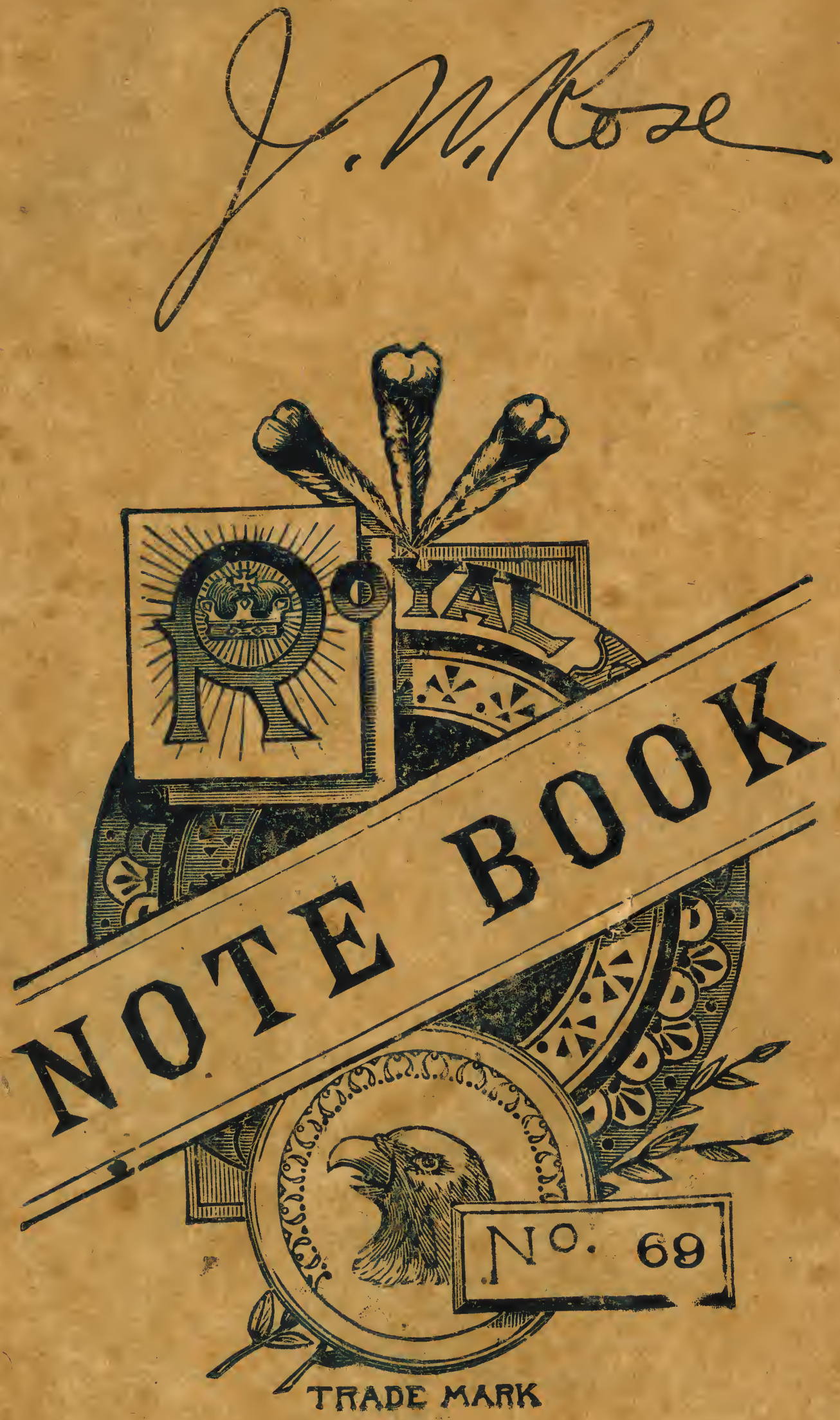




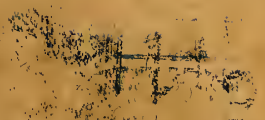

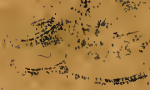

$43-4$

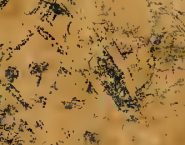

is $+4$

sit

(1)

$y^{4}+x^{2}$

a h

Seiba no/88y

The evton suaed for fillow

shecumens $(201)$ obanod ah

Concefaim lut 29/597 
The specinum (2003) uned for a buoh was rolarned in the maikst ah Acaporela-jasice, 03 
Aguacate 
Agua de cebada - Haturif BarlyThis is made ty add my towatw barley flowat on more commoney soflened tarley gaound on a "hatald" E, Augar, emmimonthaste and "ajorijoli.

The mohine is a aruddey gray color and if a swalush slucky laste. If is cenued about gheshects meentitem jass and soled for ona cents agleses. 
"Ajonjoli" - Ses ame

the seed used in makng the chnos "equa de cebadi" 
"Pifitoria"

A candy resombling ous fea rux candy is made from gound seeds t brom ougaw.

Sold on the struts of Acoforela for one eart a "dob" 
Prascecillia $=h_{0} / 41 s-$ Randha

The wood of this sheub is useel mmaking shoepego. The sfue imars (204) were touglen at Gcaponeta Geug 1/897, fuce, 07 


\section{Aqava fibur.}

Todan (ang 8) I paw the buro Amdioms making nofpe outry Aguve fibu: The Agave med in a shoutleaved shecis

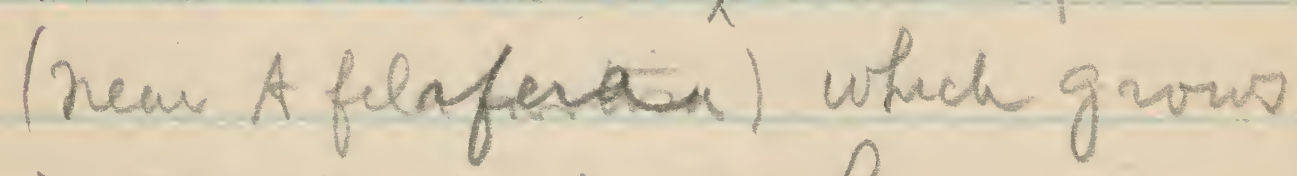
nu the houmlanes her. The filur is neary a forthong strait and fine ignd neanty wha in colver. The spining poth Thead mota and is heeformed by hirfusons one of whom fust ghe thead and ghe o ther turst otw end. The mithomunt uned in tivoting is confored of insparto. One is flattend and about Iffleong with a 
hole neaw the tof and a bove this where there is a notele. The second ferec is a - bout Ifter.ing and avond witt axmall smellentragh wo unefrecly mithe Hare of the Isterier. Ahore and os a now which frevents the Dhice beng fulled throng tho white oftur fust.

In making the end as well as in Apming the thread the corde is faslened on the sute $b$ of the funt beice which is Them rapudhy sevolved by The frevon who is domg Ohe lursting 
Asthe end lengtion the ferson who is turstiong gratually receds mali a and 40 to bo fh perlefo lons hasben otwm. Then ghis snall end is doubbl and The twonling coutraued Dometrus both heroons nesing an instuminent butturistimg mofpositedirection The coud is the dowbel again t the seme frocess eontmued These mstumenorts an Inade of vavious material. Ore whil Opouchased at San Bhaseto was made of Qre deen at Senta Theresa 
Wasmade F/ 13 mblo-which They call "Otate" ak Semba

a deffernt mokerunaturas peen for opmmot the threat. A stick futalo with a nitote as mithe atrue near the end: below the muddh is Geas a small whell $8 \mathrm{~mm}$

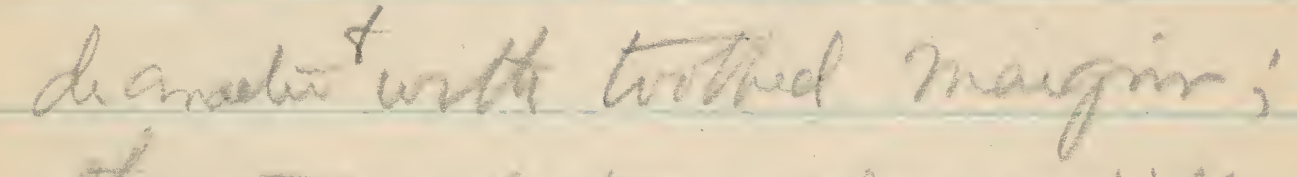
Thes is made to revitive rabidly by stivikng the whed witte ibou $\bigcirc$

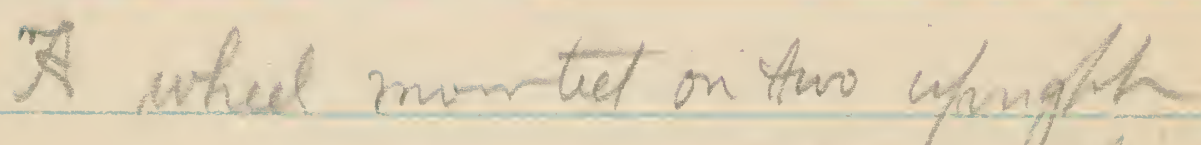
perees is uned is tursting Ine conds; then are fustered at the andelfite axis sutheita of 
Wowh ith apht, There are

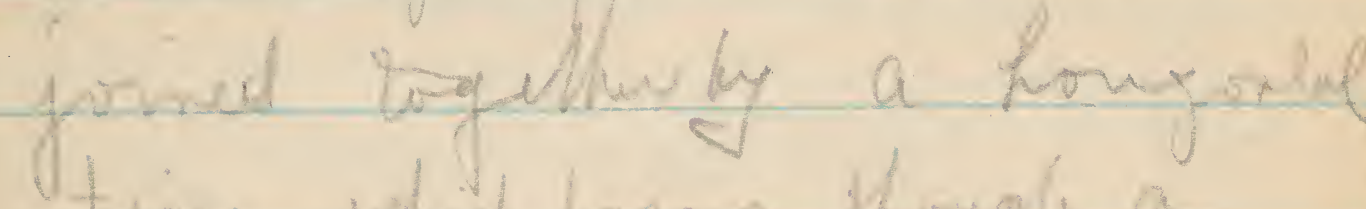

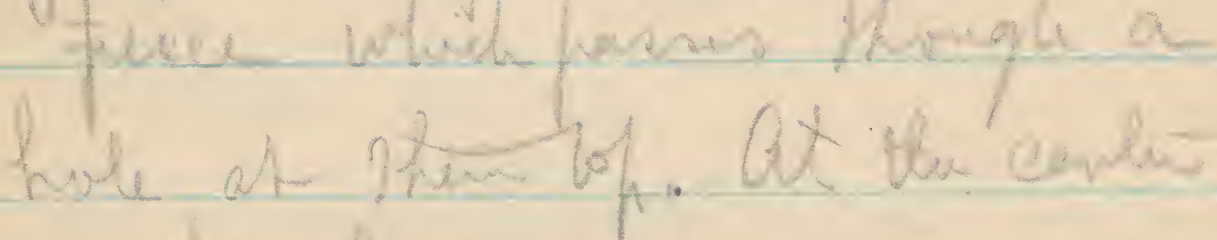
A the prowabal Wher is a panael whel 9 ma m desmebis. Whe end of thas pevies vo a. Thinall hom 2 interng tortula The fober to fosteneel.

The $y$ whel tata anpiramale ta nervene rafudly by a tweng whek tornth the jobew. Yha deal by the fewew who

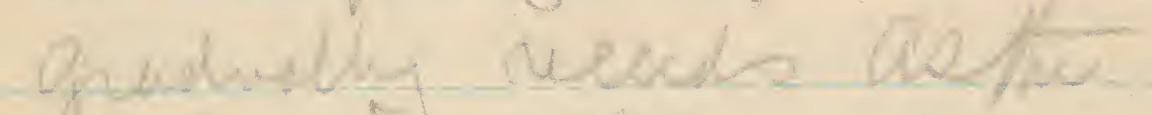

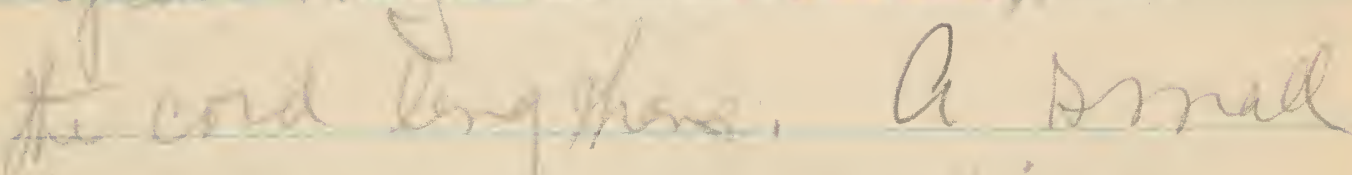

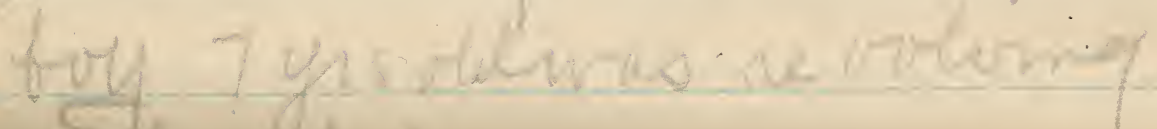

\section{the whouk}

ot uprught fuices, The where and it capishy and The eard is Dow buraled

hos the instimnomis no 6 the leave from which the

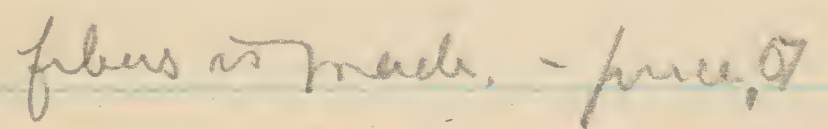
tw 7 The filue as th in sperm ho 8 the copt compleat = pare. $/ 2$ Ul these weic otand foor The Covo Indians hoy an Som Beaselo $20-3,7,8$ arsem Teresa

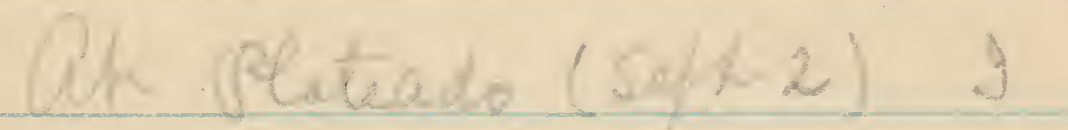

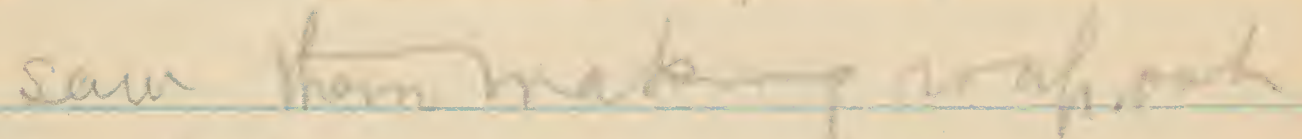

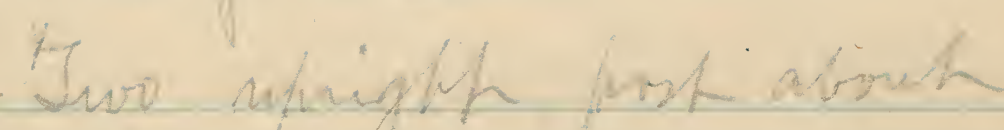

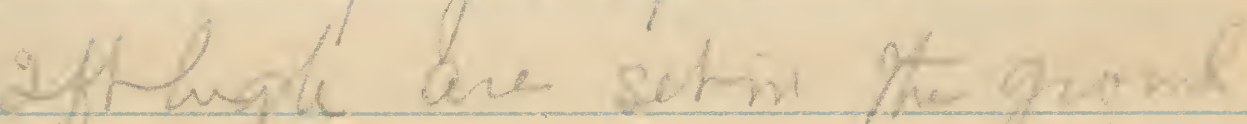


Papa $=2134-$ Potato

The wild fullat is common

ahout Senta Leresa and is guthend and entencyth Cro sndears 


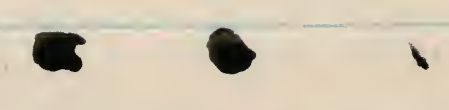

$\because 2$

brass. -20 9

This is a shec rmm of the grass med in covering the huts of the Lndeans 5 mounlamears. Shecimm latem from a hut a Pecho Panfo. Aug. \& /97. 
Agare

po 10 Phifs of tewill agare eneed at bolomer for ly uppackages of kugew

holl. Leaies fagare gammuthre unedoy bov Induans for mok ga frie four whilh is Dum netrogs ete ho/2 thes fiber, frice, 0 2013 a bag Af wor for abro funis callad 


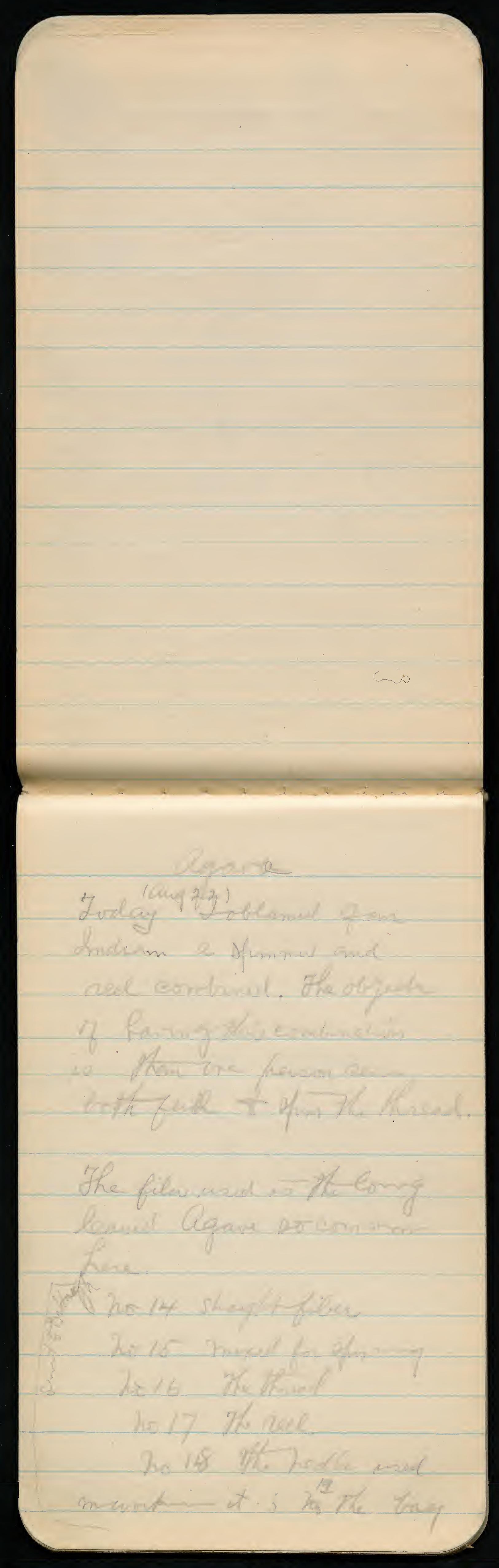




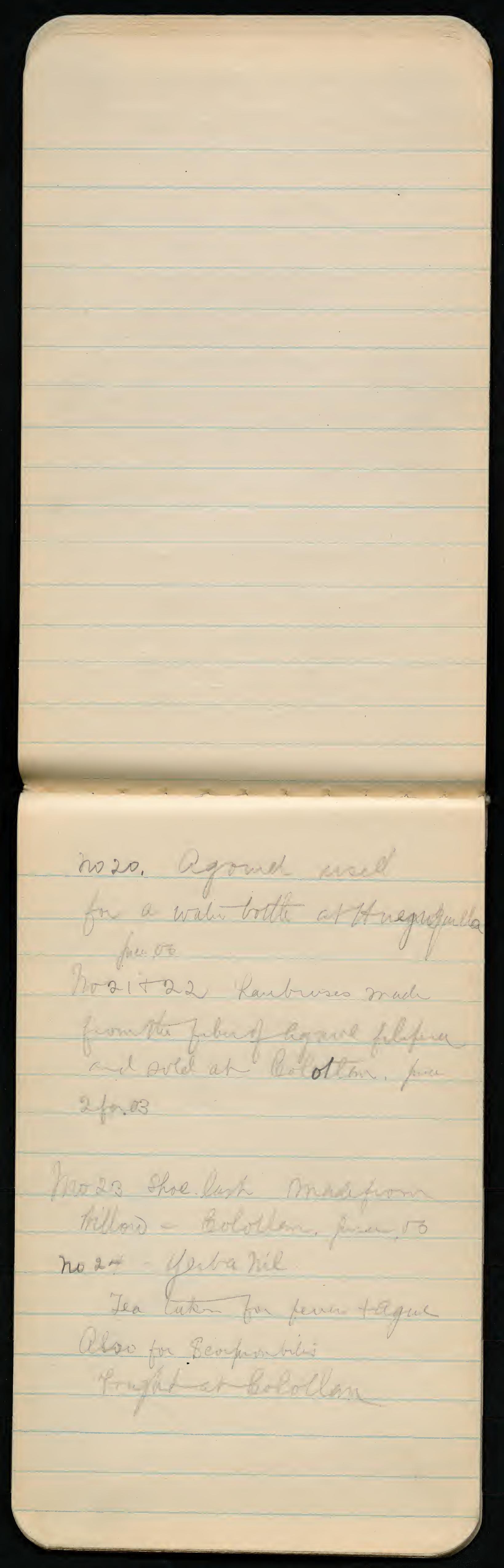




Ivday (ang 30) Q Qsur he hafers fiem hats.

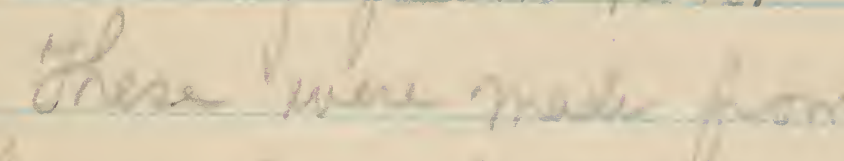
Weww bonglet fuma Lapesco a frrea torm new Tequila Yhe lewwe are outs atile thenched,

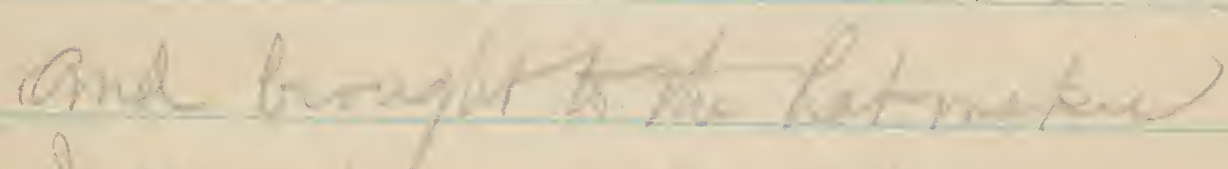

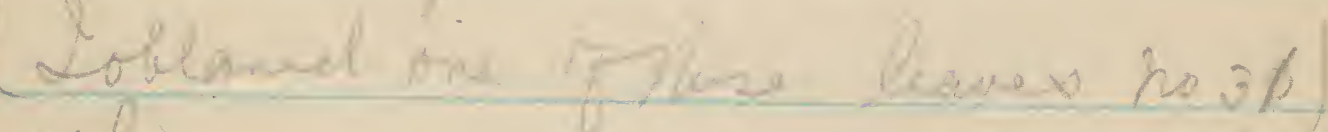

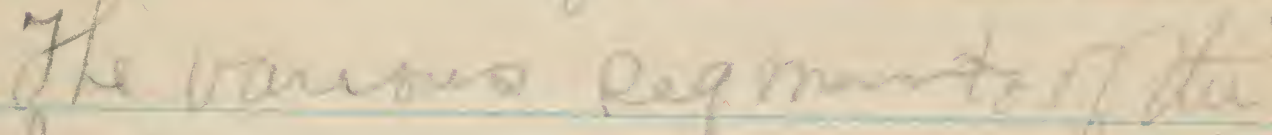
bot berme extotun or Phan wath to we dese agnon

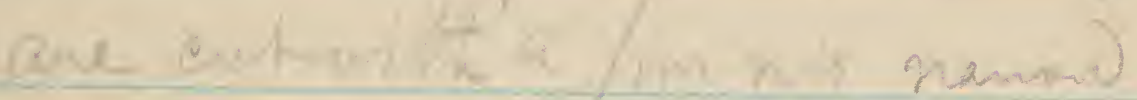

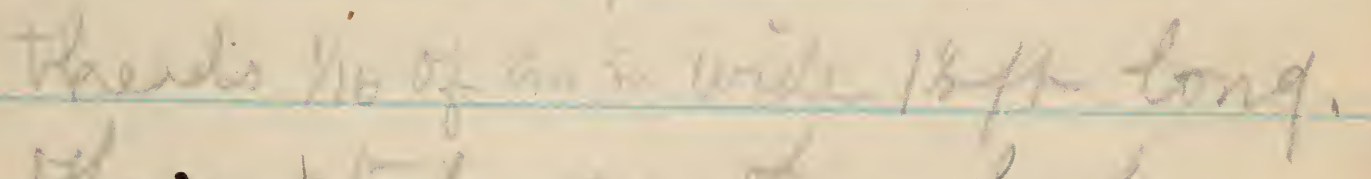
Mh. phete ar pon trote

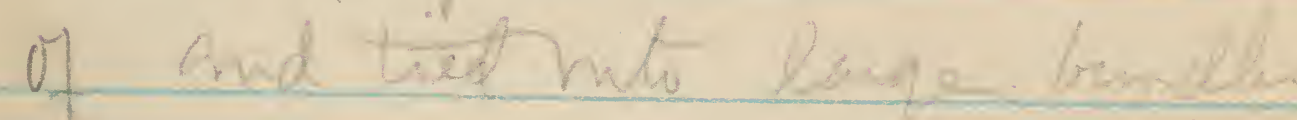
(sa) 20.32$)$

Sone bif there date one 
Ther lakere and workel onte

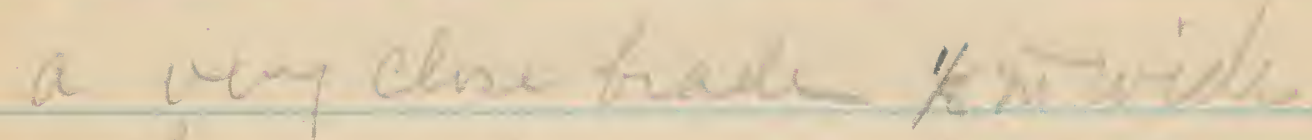

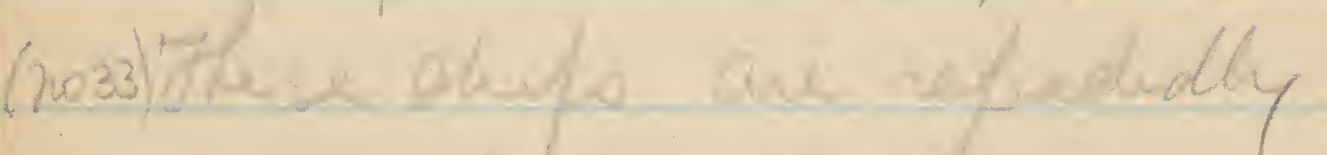

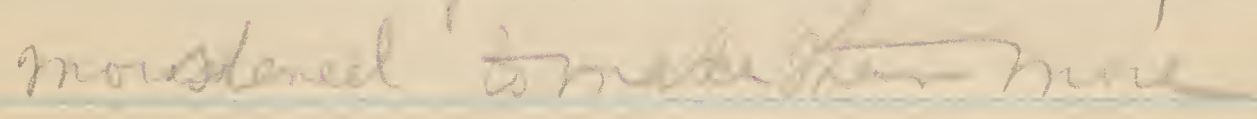
Whable, Rost whand de twale Whe ot paster twomed ot as this bemeg worked mo

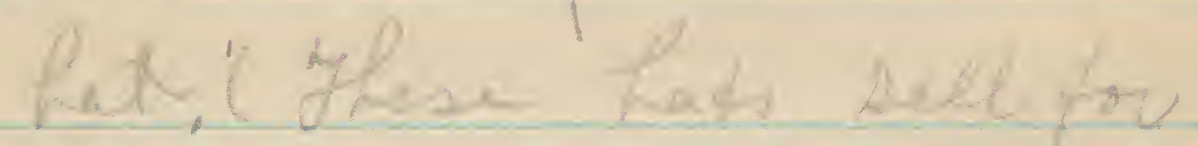
10.00 Ther ane fubstupon

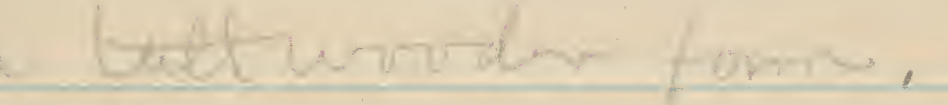

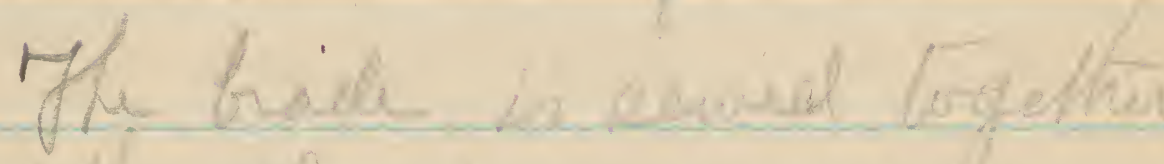
theod sowe furn This thead tomade by the

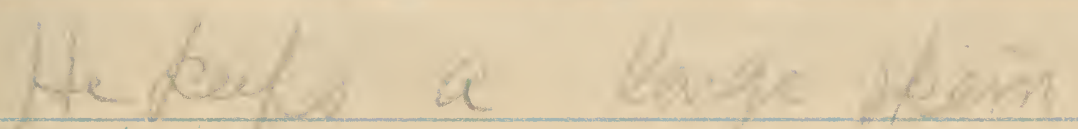



The farant is purken the Rame is the Lequela fiant it is tosne-tmis ealled the sastart Lequila

策 40 shifg the leaf. Titer is mach from the leaveo Ih is veny eoase $f$ still and used for makng crato. If is cleaned son the filowing manmer. A toand Aorie 8 murde is eeth of at an angle $p$ about Lto 0 the affer and reaclinig a mans want. the margmal fuckbles are eutrfy and the teaf then pelacention the traid. Histher scuefed with a ancle knofe fush from one and them from thother 


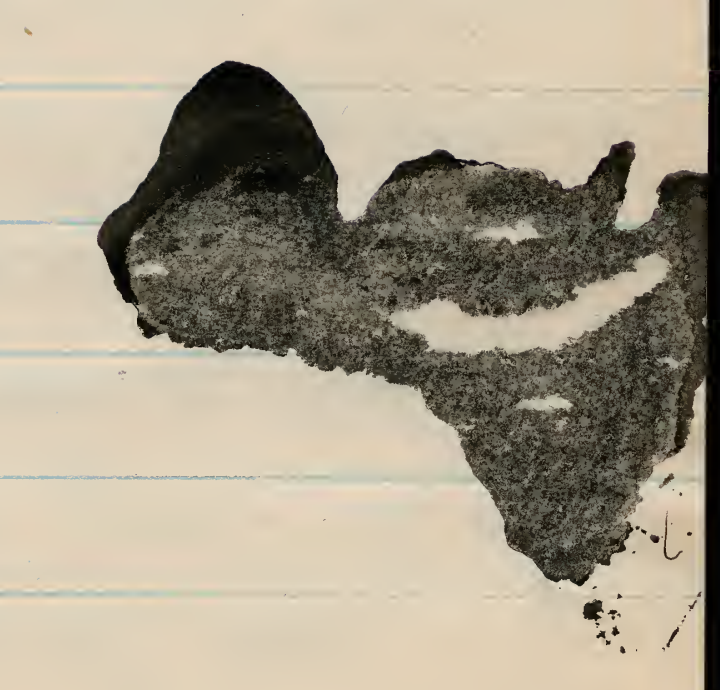

them ith is hersed over trouseme prarcess is refeated. The leat is held in flace by having one end thesred

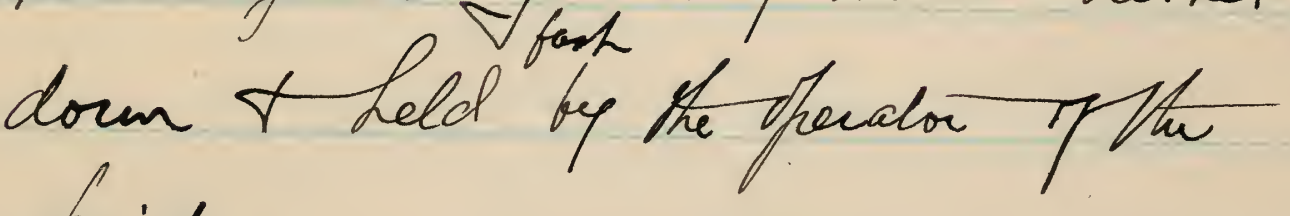
prife. hot6 the pactial cleared fiber host7" cleaned fober ho 48 . fiber ready for s/anmeng,

Saddh sureatur calbel "Suadaderos" are made at $7 \mathrm{~m}_{1}$ le lith subua of

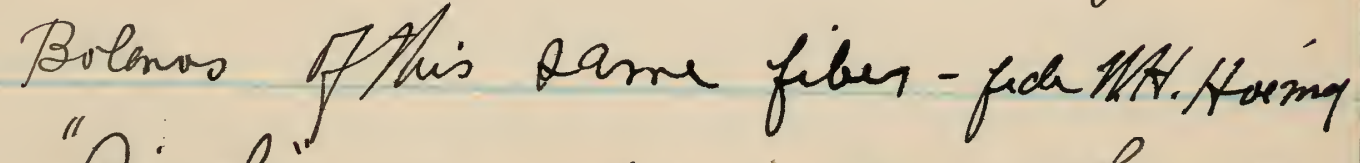
"Cinchas are also inade Jthis fiber As well as fiber made from A. filifera 
Peano- Frijoles.

Lo in truor fortelano A small buff bem sred ah Dollan Aug2g/ay.

no 49 Fingive afastedo A small furflish, somewhoh moitted with tuff brughth at Bolamos befh 12/97 furce, o7

hoso

A small coumelish fintish bean tought at Bolanos sttrylay pure, of 
$203 \%$ = fgare

Leaves (bases onm) pthe wed

Agave sold on the Plaga ot Bolanes

for bushor - 3 for 0 .

Jis ragney is ealled Zapemete brth at Bolanos and at Sanferar Cahustrano.

"kib fiber is sofer and shonger Item the "Avala" fiber

20 52

mat macle from green solot leave: frugith at Bolamos befto 1897 hiee. o3 
20.53

6 arsours belongrng the thii choles Inchans geven to tre by M. Hoing

ho 54

Mrein Auchole anow used minareng the fifugles pach of the cotton pponner.

har33-Cotton of innu, - "trompa"

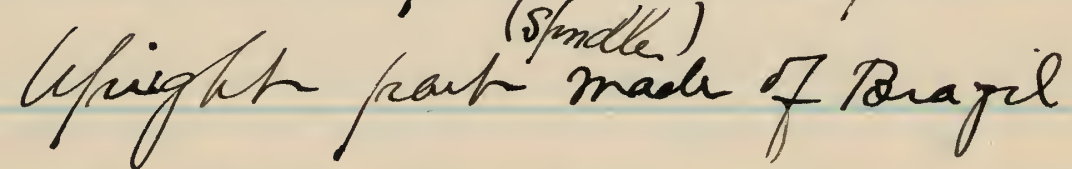
word; the whol of enon word.

Ro 56

Thead $t$ cotion hos - corton with seed. ho 58 colton falls 
ho Hol Irila oblamel at Bolanios seft.18/97

tobo strila fiberused for dish cloth oblamed ah Polanios.

hool

Qmole-

Doriglet at Bolmas Left/s/ay.

Used by all famlin ah

Boramis, Colbcting this cort

is the chef occufation 1 many

Hwichole indians who fing

loach of the norto to

dovemis, bolditan ele and poll of bery cheaf. 
2062.

Ixt. Grass used in truffing st prack saddls, coveing huto Mt. Cblained intuts west of Soramos, Sefh. 17, loy

2063 - Lanreil

Used for eold-taken as a tea -i Clas used to flavr wasle meet. 


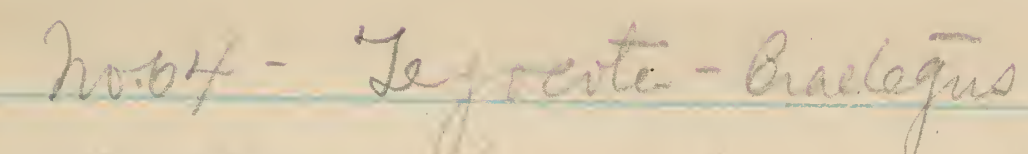

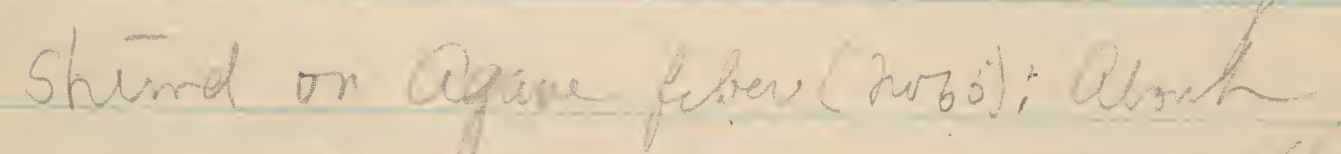

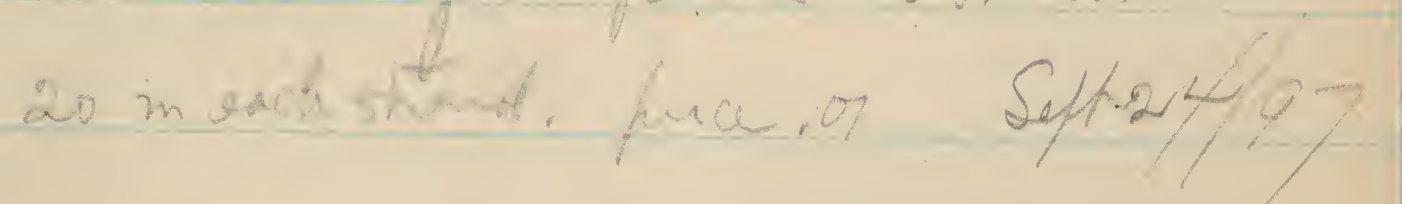

hoss: ligane fluea:

fuber anles Isote

Jejucote

$20,66=20$ te fibu ready fre

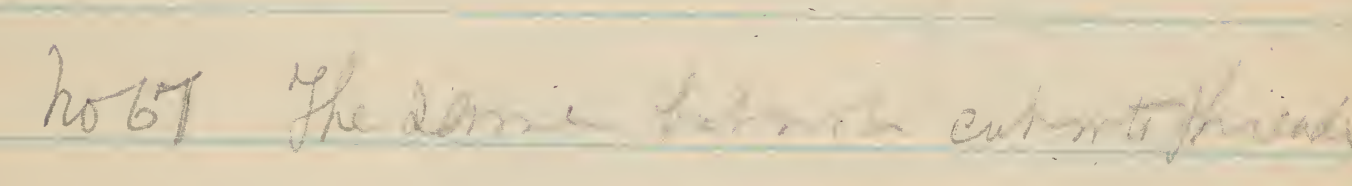

bobs the dote Tosa. 


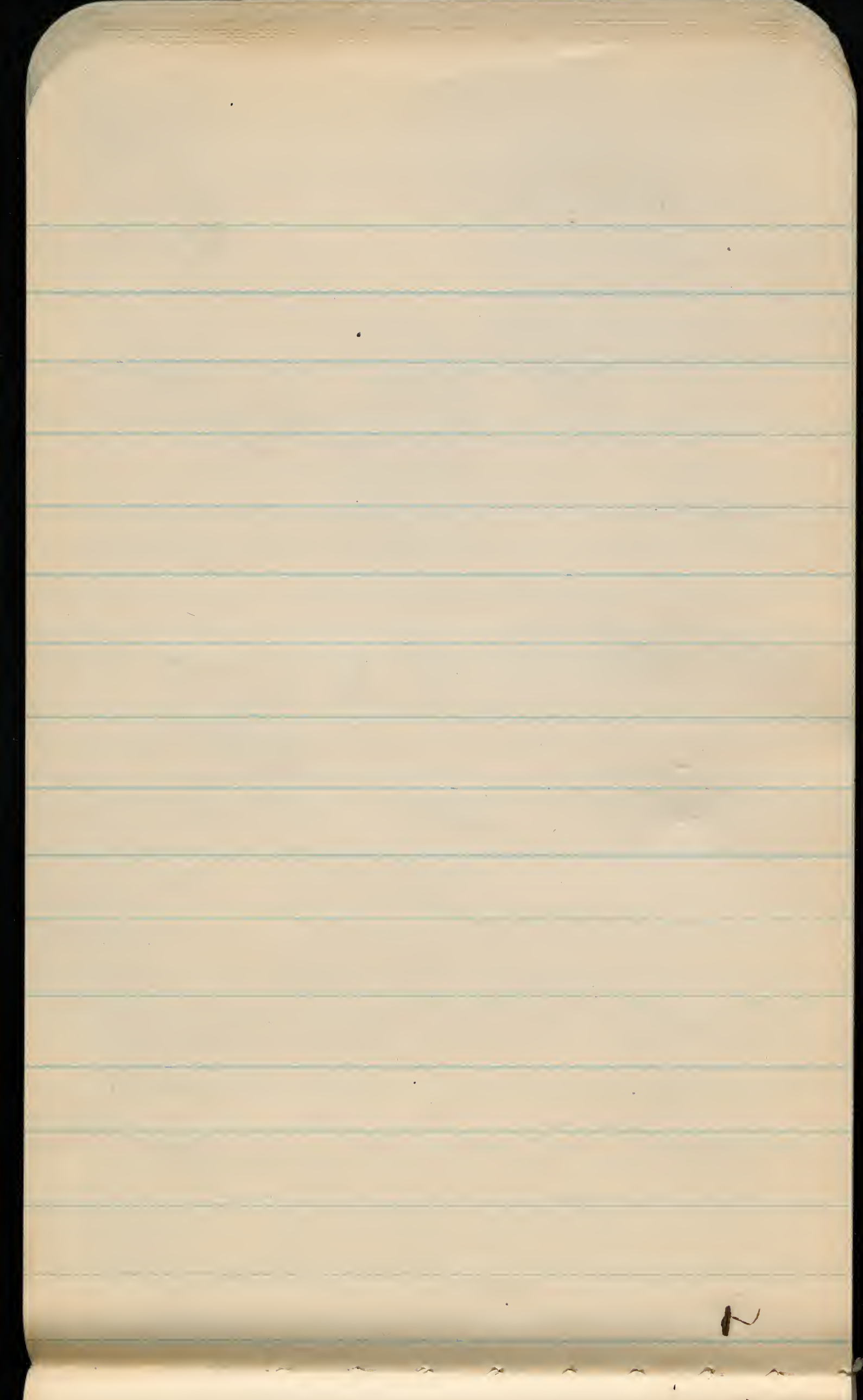



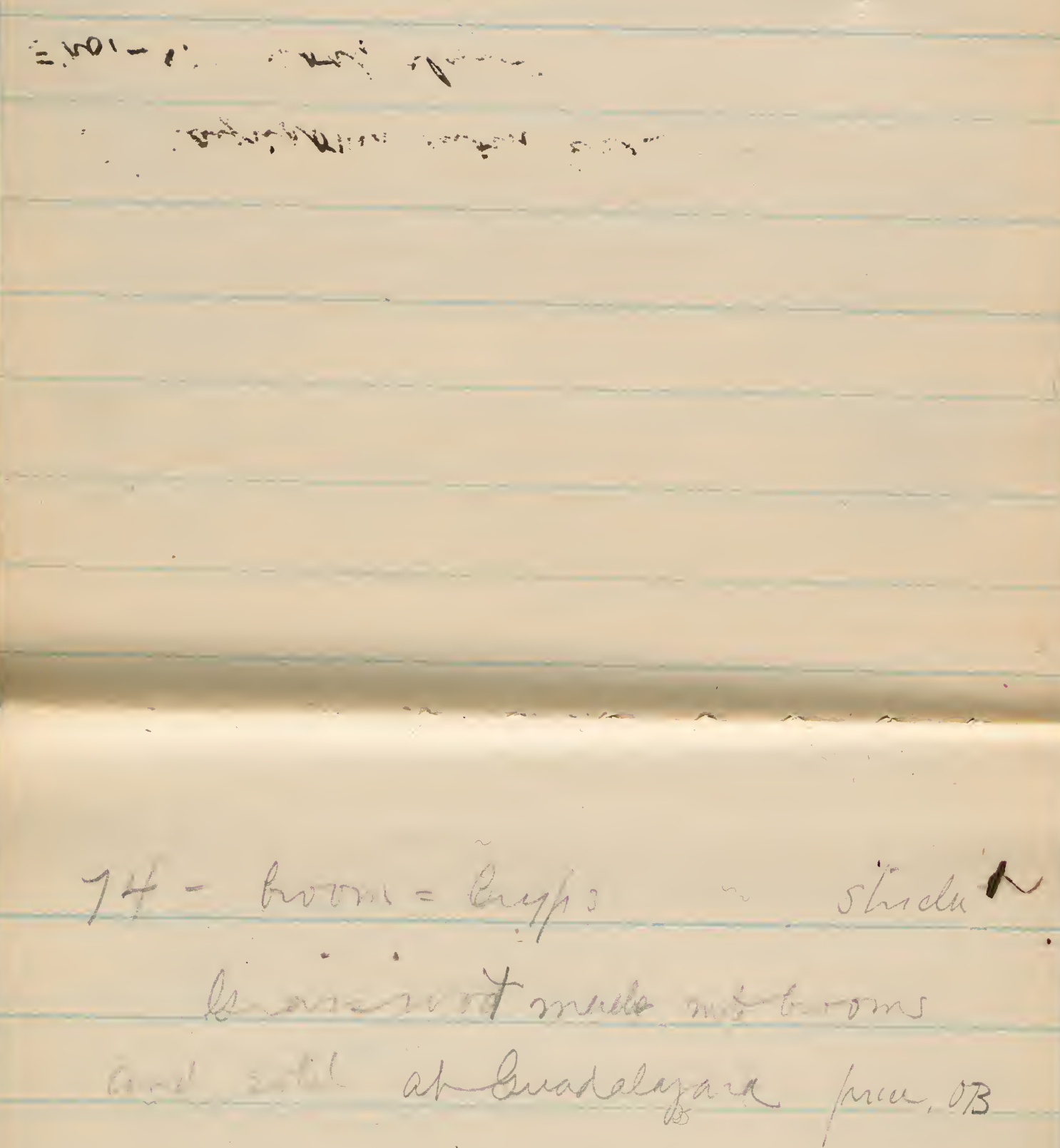

75 Bayafonia dutia Pre

$\left(=\pi_{0} / 48\right.$ ) Doop/phant

76 Boorllea mexicama

* "Lobemadora" used ar a medicine.

77 Surtemia

= Venodillo

78 Yeuba de Zou

= Lennia lmearis pertt (3079) 
บ?

SMithonian InStitution. UNITED STATES NATIONAL MUSEUM. MEMORANDUM.

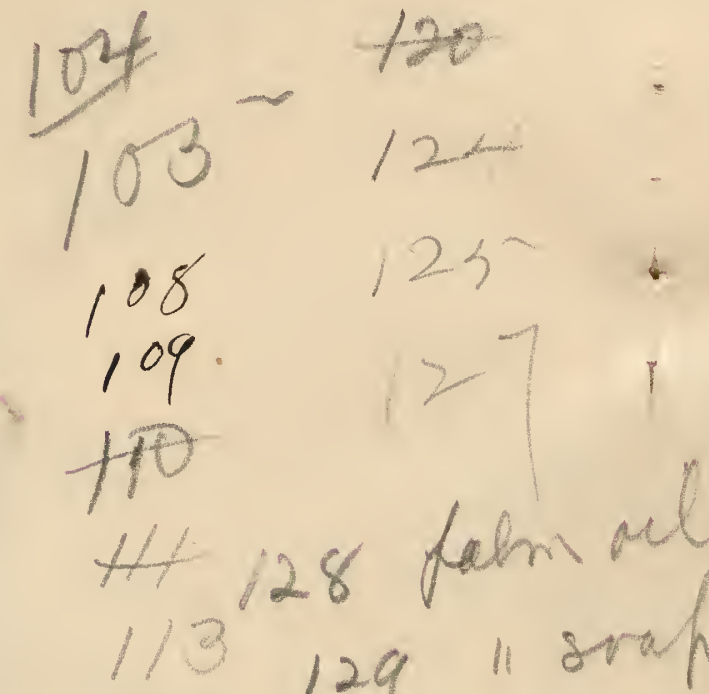

$$
\begin{aligned}
& 1 / 3129 \\
& 135180 \\
& \text { Ho } 160 \text { ton } 10 \\
& \text { H7 10\% } 108\} \\
& \text { Ho } 108
\end{aligned}
$$

84 Aurnuchil-Pticolobum dulce 
Smithsonian Institution.

UNITED STATES NATIONAL MUSEUM.

MEMORANDUM.

$\begin{array}{ll}104 & 120 \\ 103 & 124 \\ 108 & 123 \\ 109 & 127 \\ 10 & \end{array}$

H/ 128 formal 113129 l sarah 45 120

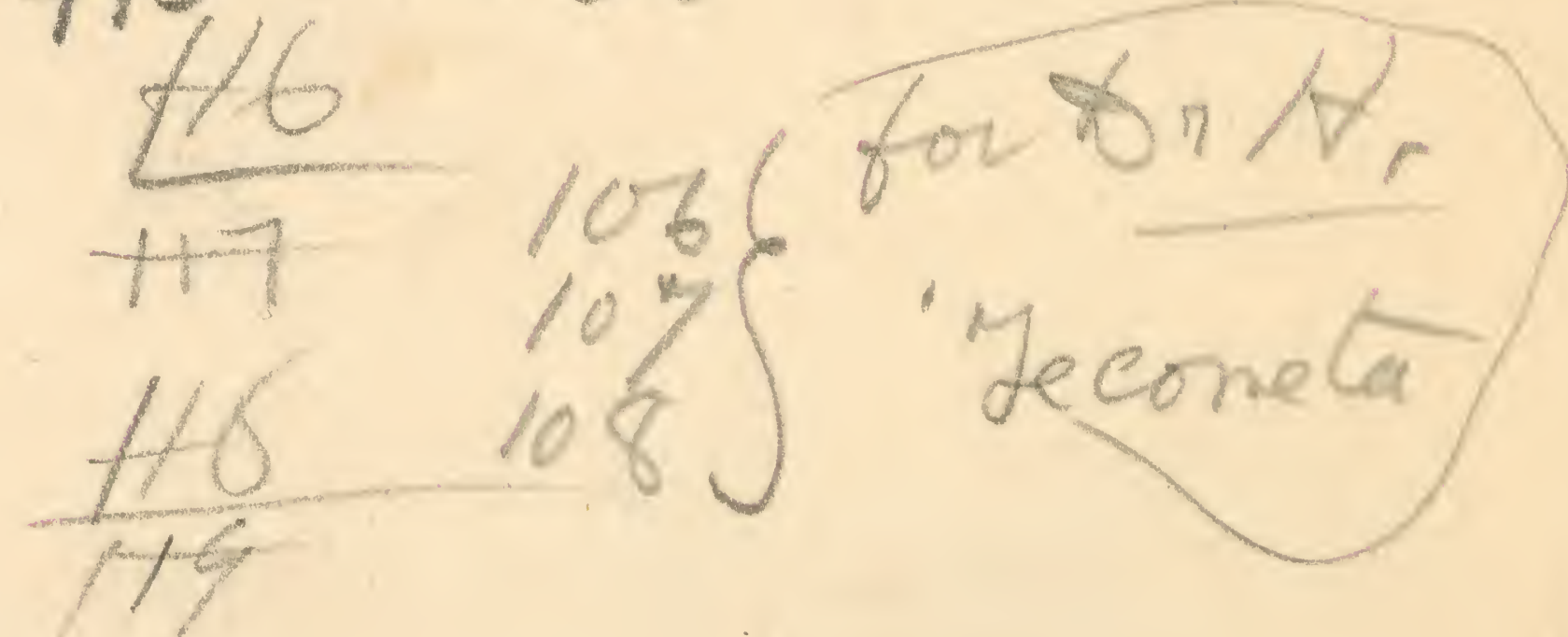






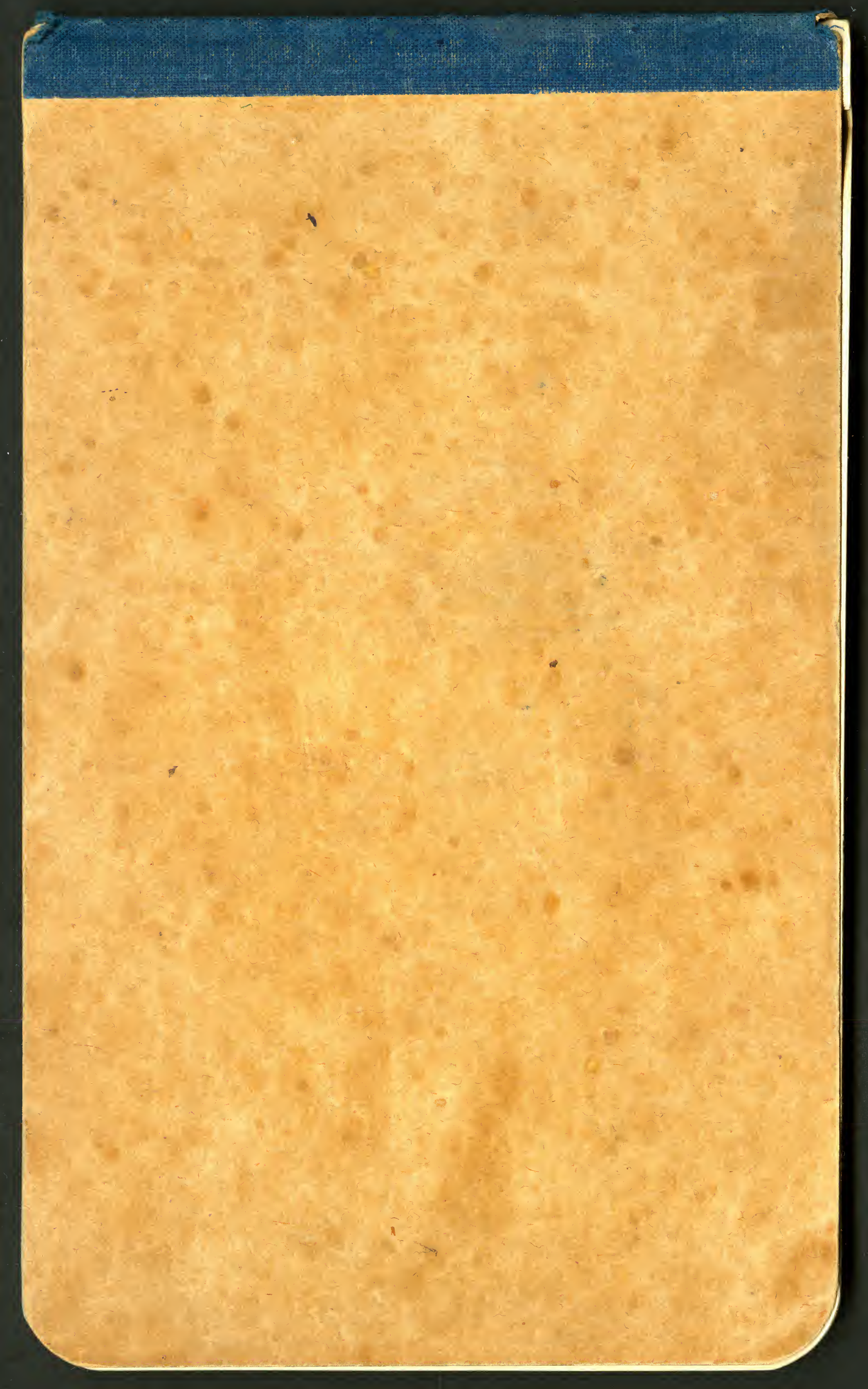

